\title{
Potency of Super Red Dragon Fruit Flesh Extract (Hylocereus costaricencis) in Herbal Lipstick as Colorant, Antioxidant and Antibacterial
}

\author{
Lusiana Dian Anjarsari ${ }^{1}$, Dwi Aditiyarini ${ }^{1}$, and Guntoro ${ }^{1^{*}}$ \\ ${ }^{1}$ Faculty of Biotechnology, Duta Wacana Christian University, Yogyakarta, Indonesia
}

\begin{abstract}
Lipstick is one kind of cosmetics which is used as lips colorant to increase self-confidence. Nowadays, lipsticks from natural source is popular to reduce the negative impact of chemical compound or synthetics colorant in lipstick intensively for health. Super red dragon fruit is one kind of natural ingredients which can be used as colorant for lipstick. Moreover, this fruit is rich of antioxidant and antibacterial component that is good for skin health. In this research, extract of super red dragon fruit flesh was added in the lipstick during preparation with variation of concentration $0,10,20,30$ and $40 \%$. Antioxidant analysis resulted the $\mathrm{IC}_{50}$ value in $81.55 \%$ indicating the strong antioxidant properties. Furthermore, the concentration of dragon fruit extract $40 \%$ was able to inhibit the growth of Staphylococcus aureus bacteria.
\end{abstract}

Keywords: dragon fruit, lipstick, colorant, antioxidant and antibacterial.

\section{Introduction}

Nowadays, cosmetics is intensively used by both men and women as to treat skin, improve the appearance and increase the self-confidence in the community. Lipstick is one kind of cosmetics products which is used to care for and beautify lips. This product is used intensively to keep the colour in lips. Unconsciously, this behaviour increases the possibility of its ingredients to be consumed and accumulated. The accumulation of chemical compounds in the body can inflict the serious health problems, such as allergy, irritation, poisoning, tissue damaging, cancer and death. The synthetics chemical compounds are generally used as colorant, preservatives and flavouring in the ingredients of lipstick. According to this problem, the production of lipstick using safe ingredients from natural products is being developed to maintain our health and prevent the health problem.

Natural ingredients for cosmetics are generally obtained from the plants and

\footnotetext{
*Corresponding author:

Guntoro

Faculty of Biotechnology, Duta Wacana Christian University Yogyakarta, Indonesia

Jl. Dr. Wahidin Sudirohusodo 5-25, Yogyakarta, Indonesia, 55224

E-mail: guntoro@staff.ukdw.ac.id
}

fruits that contain the coloured compounds. One of the natural ingredients for the natural colorants is super red dragon fruit (Hylocereus costaricencis). This dragon fruit variety is known to have many benefits for health, such as the high antioxidant content and antibacterial properties. According to Abijeet (2012), super red dragon fruit could be used as the additive in food, medicine and cosmetics. However, the use of this fruit for lipstick is limited. Moreover, the effect of this fruit as antibacterial and antioxidant is not much known. Through this study, the potency of super red dragon flesh will be explored and developed in specific for antioxidant and antibacterial. Its extract will also be developed as a material for a herbal lipstick.

\section{Material and Methods Samples}

The materials in this study consists of $1 \mathrm{~kg}$ of super red dragon fruit (Hylocereus costaricencis) aged 5 weeks, red colour and fresh. Its rind has been separated from its flesh which give $600 \mathrm{~g}$ of its flesh. The fruit flesh is the main component in this study.

\section{Extraction of Super Red Fruit Dragon Flesh \\ Extraction is done in this study by} squeezing the fruit flesh, then added $100 \mathrm{~mL}$ aquadest and filtered to obtain the extract. 
The half extract was evaporated using rotary evaporator to obtain the crude extract, whilst the half was used to the production of lipstick. The yield was calculated using Equation 1 (Eq.1).

$\%$ Yield $=\frac{\text { The weight of obtained extract }}{\text { The initial weight of simplisia }} \times 100 \%(\mathrm{Eq} .1)$

\section{Phytochemical Screening}

The phytochemical screening was done to detect the flavonoid, saponin, tannin and alkaloid compounds in the sample.

\section{Flavonoid Assay}

Zero point three (0.3) g of fruit flesh extract was placed in the test tube, then added $3 \mathrm{~mL}$-hexane and shaken roughly until producing no colour in the liquid. Next, $20 \mathrm{~mL}$ ethanol $80 \%$ was added to the liquid and divided into 3 parts. B1 solution is a blank. B2 solution was added $0.5 \mathrm{~mL}$ concentrated $\mathrm{HCl}$ then was heated on a water bath. B3 solution was added $0.5 \mathrm{~mL}$ concentrated $\mathrm{HCl}$ and 4 pieces of magnesium. The changes of colour were observed. The formation of orange solution shows the content of flavonoid (Sangi, Runtuwene and Simbala, 2008).

\section{Saponin Assay}

Zero point three $(0.3) \mathrm{g}$ of fruit flesh extract was placed in the test tube, then added $5 \mathrm{~mL}$ aquadest and shaken roughly for $30 \mathrm{~s}$. Positive result is shown by the formation of stable bubbles on the surface of the solution for $30 \mathrm{~s}$.

\section{Tannin Assay}

Zero point three (0.3) g of fruit flesh extract was placed in the test tube, then added $10 \mathrm{~mL}$ hot aquadest and homogenized. The solution was left at the room temperature, then added 3-4 drops of $\mathrm{NaCl} 10 \%$ and homogenized. The solution was divided into 3 parts. C1 solution is a blank. C2 solution was added 1-2 drops of gelation solution $1 \%$ and $5 \mathrm{~mL} \mathrm{NaCl} 10 \%$. The changes of colour were observed. Tannin compound is indicated by the formation of white sediment. If no colour changes were found in $\mathrm{C} 2$ solution, 3 drops of $\mathrm{FeCl}_{3}$ was added then observed. The formation of green to orange colour indicates polyphenol content. C3 solution was added 3 drops of $\mathrm{FeCl}_{3}$, the formation of blackish green shows tannin content.

\section{Alkaloid Assay}

Zero point three (0.3) $\mathrm{g}$ fruit flesh extract was placed in test tube, then added $5 \mathrm{~mL} \mathrm{HCl}$ $2 \mathrm{~N}$. The solution was heated up for 2-3 min while stirring, then was cooled down and added $0.3 \mathrm{~g} \mathrm{NaCl}$ and $5 \mathrm{~mL} \mathrm{HCl} 2 \mathrm{~N}$. Solution was divided into 3 parts. Solution A1 is a blank, Solution A2 was reacted with 3 drops of Mayer reactant, solution A3 was reacted to Wagner reactant. The colour changes, the formation of precipitant and hazing solution indicates alkaloid compound.

\section{GC-MS Analysis}

GC-MS analysis was done in LIPI Bogor. 1 g crude extract of dragon fruit was added $1 \mathrm{~mL}$ dimethyl sulfoxide (DMSO) the homogenized and placed in the ependorf. This sample then was analysed using GC-MS instrument.

\section{Antioxidant Activity Assays of Super Red Dragon Flesh Extract}

This assay was done for liquid extract of dragon fruit using DPPH method (1,1-phenyl2-picrylhydrazyl). $19.71 \mathrm{mg}$ of DPPH solid was weighted and placed into the volumetric flash. Then $50 \mathrm{~mL}$ methanol was added and kept into the dark bottle. Blank solution was incubated in room temperature $27^{\circ} \mathrm{C}$ for $30 \mathrm{~min}$ and wrapped with aluminium foil. For comparing, 100 ppm ascorbic acid was used, maximum absorbance was measured at wavelength $510-520 \mathrm{~nm}$. Sample was calculated at 10, 20, 30, 40 and 50 ppm at 517 $\mathrm{nm}$. Then, the graphic was plotted between \% inhibition versus concentration (ppm) which would produce regression equation. $\mathrm{IC}_{50}$ was calculated in $\mu \mathrm{g} / \mathrm{mL}$ with y value equal to 50 .

\section{Lipstick Preparation}

Eight (8) g of solid lipstick per batch was made using active compound of super red dragon fruit in the variation of crude extract concentration $(0,10,20,30$ and $40 \%)$. The formulation of material for lipstick was shown in Table 1. 
Table 1. Formulation of Natural Lipstick

\begin{tabular}{lccccc}
\cline { 1 - 1 } \multicolumn{1}{c}{ Material } & \multicolumn{5}{c}{ Concentration (\%) } \\
& F0 & F1 & F2 & F3 & F4 \\
\hline $\begin{array}{lccccc}\text { Crude extract of super } \\
\text { red dragon fruit }\end{array}$ & 0 & 10 & 20 & 30 & 40 \\
Olive oil & 33.3 & 30 & 26.67 & 23.33 & 20 \\
Beeswax & 33.3 & 30 & 26.67 & 23.33 & 20 \\
Peanut Butter & 33.3 & 30 & 26.67 & 23.33 & 20 \\
\hline
\end{tabular}

\section{Organoleptic Assays}

The stability of each lipstick formula was done for 3 weeks with the evaluation every week. Lipstick was kept at $27^{\circ} \mathrm{C}$ and $37^{\circ} \mathrm{C}$. Evaluation were done for the physical appearance (formation of crystal and sweat), smell and texture.

\section{Peroxide Number Assays of Lipstick}

Peroxide number is an indicator to determine the level of oil damage or fat as a result of oxidation reaction in the storage condition. In this assay, peroxide number was done for determine the antioxidant concentration in the lipstick during storage.

\section{Standardization of $\mathrm{Na}_{2} \mathrm{~S}_{2} \mathrm{O}_{3}$ solution.}

$10 \mathrm{mLK}_{2} \mathrm{Cr}_{2} \mathrm{O}_{7}$ was added to Erlenmeyer, followed by $2.5 \mathrm{~mL} \mathrm{H}_{2} \mathrm{SO}_{4}$ solution and 5 $\mathrm{mL} \mathrm{KI} 20 \%$. This solution was titrated with $\mathrm{Na}_{2} \mathrm{~S}_{2} \mathrm{O}_{3}$ using amylum as indicator. Titration was performed until dark blue colour disappearing. The concentration of $\mathrm{Na}_{2} \mathrm{~S}_{2} \mathrm{O}_{3}$ was calculated.

\section{Determination of Peroxide Number.}

$1 \mathrm{~g}$ lipstick was put into the Erlenmeyer flask $50 \mathrm{~mL}$, followed by the addition of 6 $\mathrm{mL}$ acetic acid glacial and $0.1 \mathrm{~mL}$ potassium iodide saturated. Erlenmeyer was closed and wrapped to prevent from the sun radiation, and leaved it for $1 \mathrm{~min}$ while homogenized. $6 \mathrm{~mL}$ aquadest was added, the solution was titrated with $\mathrm{Na}_{2} \mathrm{~S}_{2} \mathrm{O}_{3}$ using amylum as indicator until the dark blue colour disappear. Peroxide number of lipstick was determined using equation 2.

Volume of $\mathrm{Na}_{2} \mathrm{~S}_{2} \mathrm{O}_{3}$ from titration $\times$ Normalitas $\mathrm{Na}_{2} \mathrm{~S}_{2} \mathrm{O}_{3} \times 1000$

$$
\text { sample (g) }
$$

\section{Antibacterial Assay}

Antibacterial assay was done to know the antibacterial activity of this compound to Staphylococcus aureus bacteria. Bacteria was cultured in to Nutrient agar medium (NA) and nutrient broth (NB) and the number of bacteria was calculated for $100 \mathrm{uL}$ medium each petri dish with pour plate method. Plate was group in 4-5 zone to facilitate the treatment. Then, the small holes were made to put the sample. After the sample was put, each petri dish was incubated in $37^{\circ} \mathrm{C}$ and observed for 24 hours in aerobic condition for $S$. aureus. The ability of antibacterial was observed from the inhibition area which was formed near the holes. The diameter of inhibition area was measured. This assay was done for the formulation of lipstick which was stored for 1 and 3 weeks at either $27^{\circ} \mathrm{C}$ or $37^{\circ} \mathrm{C}$. This assay was also performed for extract of super red dragon fruit and the commercial lipstick.

\section{Result \\ Extract of Super Red Dragon Fruit.}

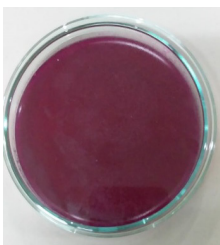

Extraction produced $450 \mathrm{~g}$ liquid extract with red colour (Fig. 1) from 600 gram of super red dragon fruit flesh which gives yield $75 \%$.

Figure 1. Extract of super red dragon fruit (Hylocereus costaricencis).

\section{Phytochemical Screening}

Flavonoid, tannin and alkaloid compound was observed in flesh extract of super red dragon fruit, whilst saponin compound was undetectable. The result showed that this extract did not contain saponin. The result of phytochemical assay was shown in Table 2.

\section{GC-MS Analysis of Super Red Dragon Fruit Extract \\ GC-MS analysis detected 19 compounds from crude extract of super red dragon fruit (Table 3). \\ Crude extract of super red dragon fruit contained some compounds which}


Table 2. Phytochemical assay result of super red dragon fruit extract

\begin{tabular}{lllc}
\hline \multicolumn{1}{c}{ Compound } & \multicolumn{1}{c}{ Parameter } & \multicolumn{1}{c}{ Colour } & Result \\
\hline Flavonoid & Orange red & Orange & + \\
Saponin & Stable bubble & No bubble & - \\
Tannin & Yellowish green & Yellowish & + \\
Alkaloid & & & + \\
Dragendorff & Red precipitant & Red precipitant & + \\
Mayer & White precipitant & White precipitant & + \\
Wagner & Haze & Haze & + \\
\hline
\end{tabular}

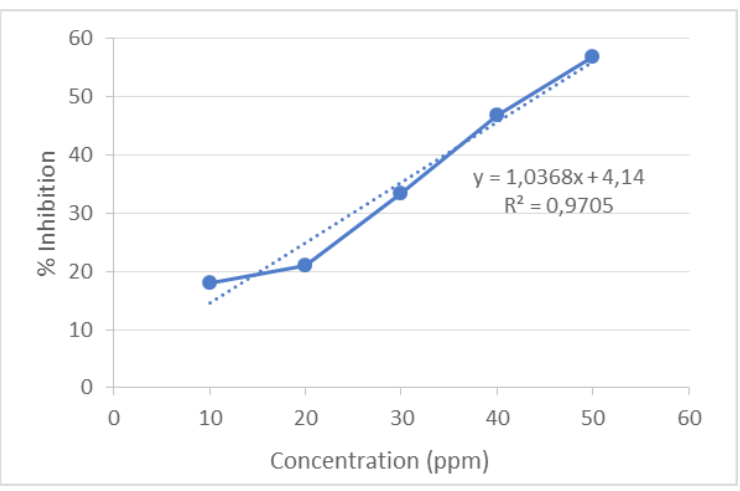

Figure 3. Antioxidant Activity of Super Red Dragon Fruit Extract.

have many activities such as antioxidant, preservatives, additive, antimicrobial, antibacterial, insecticide, fungicide and nematicide.

\section{Antioxidant Assay of Super Red Dragon Fruit Extract}

Antioxidant assay of extract was done using DPPH method. From the assay, $\mathrm{IC}_{50}$ value of this extract was $81.55 \mu \mathrm{g} / \mathrm{mL}$. The correlation of $\%$ inhibition vs concentration of extract was shown in Fig.3 for dragon fruit extract and Fig. 4 for ascorbic acid as standard.

Ascorbic acid has been known to have antioxidant activity. In this study, we used ascorbic acid as standard which has $\mathrm{IC}_{50}$ value $52.23 \mu \mathrm{g} / \mathrm{mL}$. In the comparison of dragon fruit extract with ascorbic acid, $\mathrm{IC}_{50}$ value of the dragon fruit extract is 1.56 times higher than ascorbic acid.

\section{Organoleptic Assay of Dragon Fruit Lipstick}

Organoleptic assay was performed to obtain the information about the product's stability in texture, physical characteristic, smell and colour. The dragon fruit lipstick

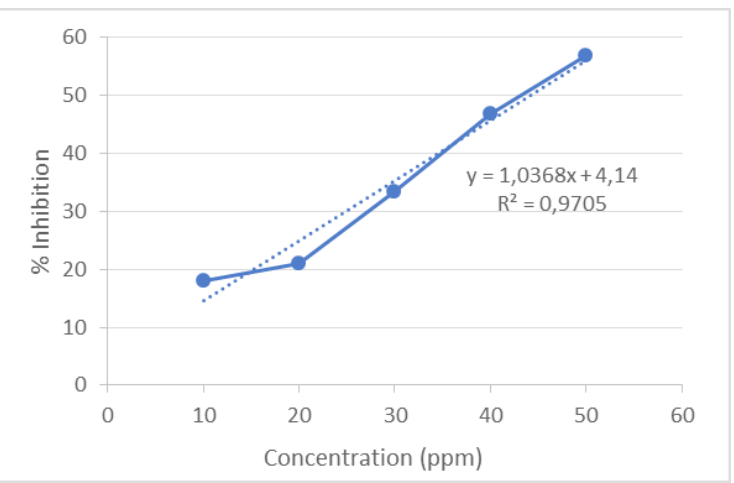

Figure 4. Antioxidant Activity of Ascorbic acid.

was made from several natural sources such as beeswax, olive oil and peanut butter which was mixed with dragon fruit extract in different concentration. The physical appearance of these lipstick was shown in Fig. 5.

For the physical characteristics, we observed the formation of crystal (C) or no crystal (NC) and sweating (Sw) OR no sweating (NSw). Then, for texture, the product was soft (Sf) or rough (R). In the case of smell, we smell that the product is fragrant (F) or no fragrant (NF). For the colour, we observed if the product is white $(\mathrm{W})$, yellow $(\mathrm{Y})$, pink (P), light purple (LP) or dark purple (DP). The result of organoleptic assay was shown in Table 4.

Most formulation of lipsticks were stable when were kept at $27^{\circ} \mathrm{C}$ for 3 weeks, except F1 and F2 containing 10 and $20 \%$ of crude extract respectively. After 1 weeks, formation of crystal occurred for F1 and F2 that changed their texture becoming rough. The changes of colour happened in all formulation during storage in different time. The colour of F0 and F3 changes at $3^{\text {rd }}$ week, whereas F1 is stable. For F2 and F4, 
Table 3. Active compounds of super red dragon fruit extract from GC-MS analysis.

\begin{tabular}{|c|c|c|c|c|}
\hline No & Compound & Concentration (\%) & Activity & Reference \\
\hline 1 & Glyceraldehyde & 4.2 & $\begin{array}{c}\text { Intermediate compound } \\
\text { in the metabolism of } \\
\text { carbohydrate }\end{array}$ & Najmiatul, 2011 \\
\hline 1 & 2-ethyl-1.3 dioxolane-4-methanol & 0.08 & Antioxidant & Wrasiati, 2011 \\
\hline 2 & hexanoic acid, octyl ester & 0.45 & Antioxidant & Wrasiati, 2011 \\
\hline 3 & Propanoic acid & 0.35 & $\begin{array}{c}\text { Antioxidant, buffer } \\
\text { agent, preservatives and } \\
\text { additive }\end{array}$ & $\begin{array}{l}\text { Smith and Hong- } \\
\text { shum, } 2003\end{array}$ \\
\hline 4 & 7-Tetradecene, (E)- & 0.13 & Antioxidant & $\begin{array}{l}\text { Balasundram, } \\
\text { Sundram and } \\
\text { Samman, } 2006\end{array}$ \\
\hline 5 & $\begin{array}{l}\text { 4H-pyran-4-one, 2,3-dihydro-3,5- } \\
\text { dihydroxy-6-methyl }\end{array}$ & 4.1 & Antioxidant & $\begin{array}{l}\text { Elezabeth and } \\
\text { Arumugam, } 2014\end{array}$ \\
\hline 6 & 3-Deoxy-d-mannoic lactone & 9.65 & Antibacterial & $\begin{array}{l}\text { Ghosh, Banerjee } \\
\text { and Sil, } 2015\end{array}$ \\
\hline 7 & 2-Propenoic acid, oxiranylmethyl ester & 0.32 & Antimicrobial & $\begin{array}{l}\text { Azam, Waris and } \\
\text { Nahar, } 2005\end{array}$ \\
\hline 8 & Ethane, 1-chloro-2-isocyanato & 0.07 & Antimicrobial & Zhao et al., 2010 \\
\hline 9 & $\begin{array}{l}\text { 2-butenoic acid, 4,4-dimethoxy-, methyl } \\
\text { ester }\end{array}$ & 0.13 & Antimicrobial & Wijaya et al., 2008 \\
\hline 10 & 2-t-butyl-5-propyl-[1,3] dioxolan-4-one & 0.29 & Antimicrobial & Devi et al., 2014 \\
\hline 11 & $\begin{array}{l}\text { Butanamide, 2-hydroxy-N,2,3,3- } \\
\text { tetramethyl- }\end{array}$ & 0.29 & $\begin{array}{l}\text { Antimicrobial, } \\
\text { preservative }\end{array}$ & Devi et al., 2014 \\
\hline 12 & $\begin{array}{l}\text { 2,4-Dihydroxy-2,5-dimethyl-3(2H)- } \\
\text { furan-3-one }\end{array}$ & 0.1 & Preservatives & $\begin{array}{l}\text { Figueiredo et al., } \\
2008\end{array}$ \\
\hline & Formic acid, 2-propenyl ester & 0.78 & Preservatives & Yatagai, 2002 \\
\hline 13 & Nonane, 4,5-dimethyl- & 0.14 & Preservatives & Yatagai, 2002 \\
\hline 14 & 2-Propanamine, N-methyl-N-nitroso- & 3.11 & Preservatives & Uma et al., 2009 \\
\hline 15 & 2(3H)-Furanone, dihydro-3-methylene- & 0.03 & Preservatives & Uma et al., 2009 \\
\hline 16 & $\begin{array}{l}\text { [5-Hydroxymethyl)-1,3-dioxolan-4-yl] } \\
\text { methanol }\end{array}$ & 1.76 & Antibiotic & Aydin, 2005 \\
\hline 17 & 1,2-Benzenediol, 4-methyl- & 0.42 & Antiseptic & Aydin, 2005 \\
\hline 18 & (S)-5-Hydroxymethyl-2[5H]-furanone & 0.19 & $\begin{array}{l}\text { Insecticide, fungicide } \\
\text { and nematicide }\end{array}$ & Timothy et al., 2012 \\
\hline 19 & Heptanoic acid, 6-oxo- & 1.52 & Insecticide & Timothy et al., 2012 \\
\hline
\end{tabular}

$\%$ is obtained from the area of sample in the chromatogram which represents the concentration of compound in the sample.

the changes of colour occurred faster than others, which was at $2^{\text {nd }}$ week in the storage.

Storage at $37^{\circ} \mathrm{C}$ was more risk than at $27^{\circ} \mathrm{C}$. It resulted the changes of physical and colour faster than at $27^{\circ} \mathrm{C}$. The colour of F0 and F2 started to change at $2^{\text {nd }}$ week, whereas $\mathrm{F} 1$ at $3^{\text {rd }}$ week, F3 and F4 at $1^{\text {st }}$ week. Formulation of lipstick was faster to changes either physically, texture and colour when it was kept at $37^{\circ} \mathrm{C}$ compared to $27^{\circ} \mathrm{C}$.

\section{Peroxide Number Assay}

The dragon fruit lipstick was composed of the fatty compounds such as olive oil, beeswax and peanut butter which could undergo oxidation process. This process
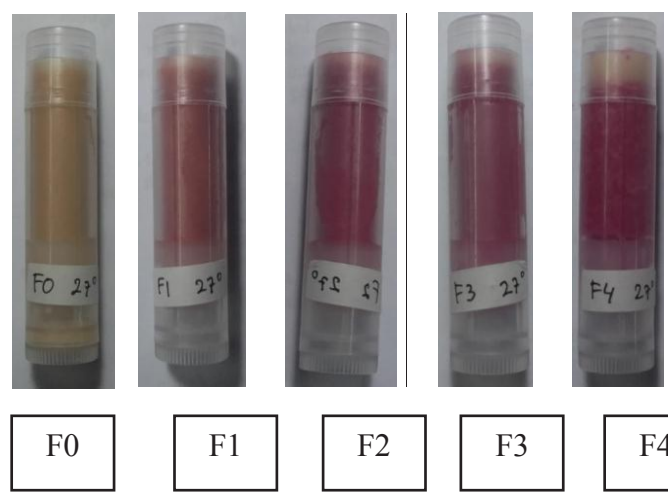

F4

Figure 5. The natural lipstick from the dragon fruit extract. F0: lipstick base, F1: containing $10 \%$ of extract; F2: $20 \%$ of extract, F3: $30 \%$ of extract, F4: $40 \%$ of extract. 
Table 4. Evaluation of Organoleptic Assay of Super Red Dragon Fruit.

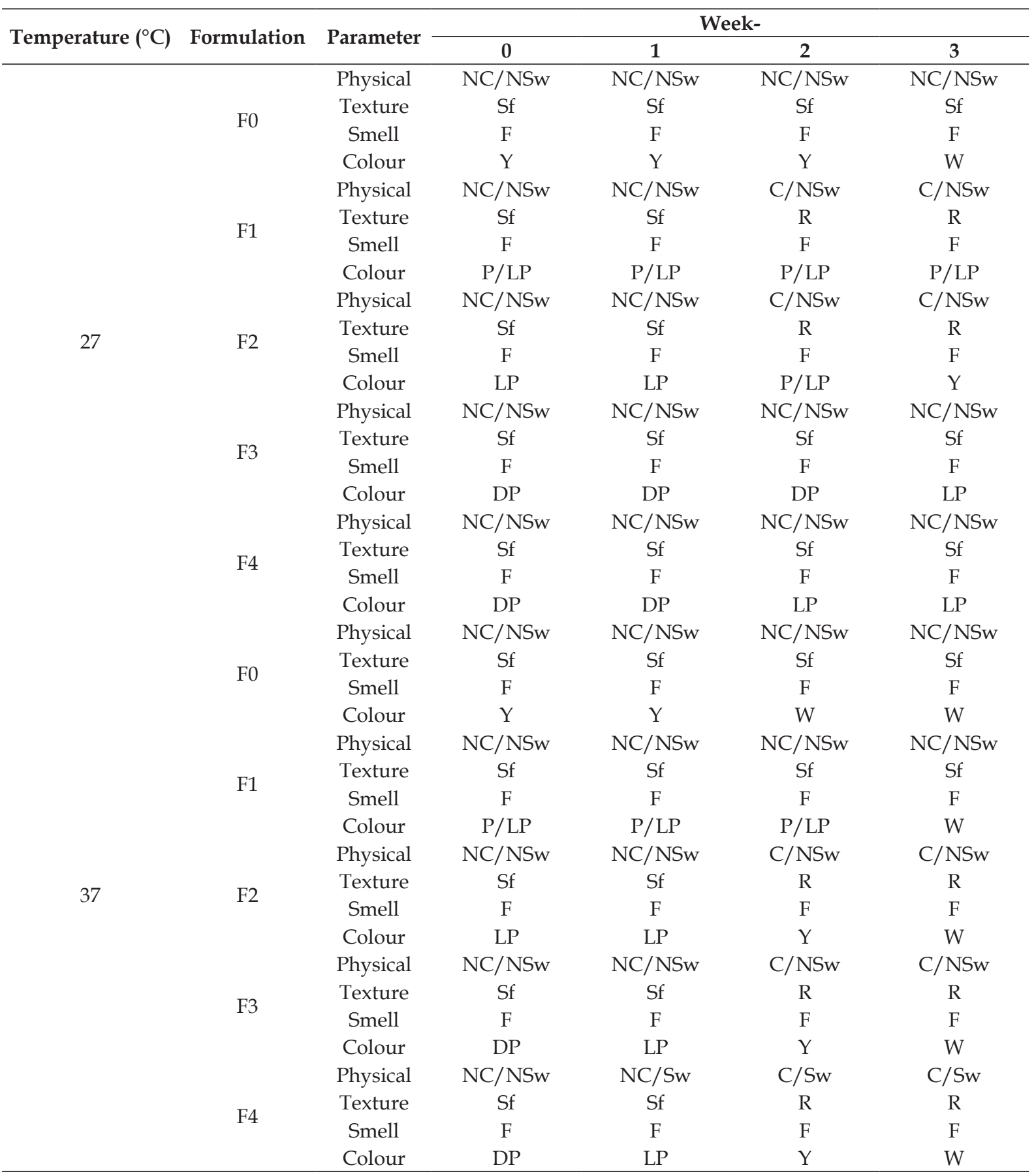

Abbreviation C: crystal, NC: no crystal, Sw: sweating, NSw : no sweating, Sf: soft, R: rough, F: fragrant, NF: no fragrant, W: white, Y: yellow, P: pink, LP: light purple, DP: dark purple.

Table 5. Antibacterial Activity of Super Red Dragon Fruit against Staphylococcus aureus

\begin{tabular}{|c|c|c|c|c|c|c|c|c|c|c|}
\hline \multirow{2}{*}{ Temperature $\left({ }^{\circ} \mathrm{C}\right)$} & \multirow{2}{*}{$\begin{array}{l}\text { Storage period } \\
\text { (week) }\end{array}$} & \multicolumn{9}{|c|}{ Inhibition Zone (mm) } \\
\hline & & + & - & E & F0 & F1 & F2 & F3 & F4 & K \\
\hline \multirow{2}{*}{27} & 1 & 30 & 0 & 14 & 0 & 0 & 0 & 0 & 25 & 0 \\
\hline & 3 & 28 & 0 & 14 & 0 & 0 & 0 & 0 & 20 & 0 \\
\hline \multirow{2}{*}{37} & 1 & 28 & 0 & 14 & 0 & 0 & 0 & 0 & 20 & 0 \\
\hline & 3 & 25 & 0 & 14 & 0 & 0 & 0 & 0 & 0 & 0 \\
\hline
\end{tabular}

(+: Ciprofloxacin, -:Lipstick Base, E:extract, K:Commercial Lipstick) 


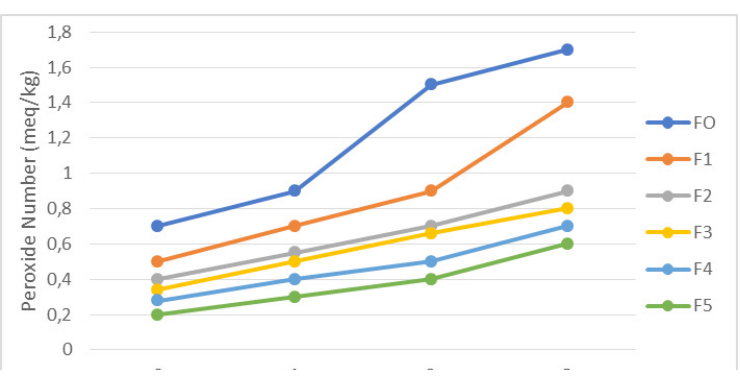

Figure 5. The peroxide number assay of dragon fruit lipstick for storage at $27^{\circ} \mathrm{C}$.

could generate bad smell for the product during the storage.

Peroxide number is a number of fatty acid which could undergo oxidation process or hydrolysis producing oxygen and peroxide compound. Through this assay, we were also able to know the antioxidant activity of super red dragon fruit which reduces the bad smell and taste. The result of peroxide number assay was shown at Fig. 5 for storage at $27^{\circ} \mathrm{C}$ and Fig. 6 for $37^{\circ} \mathrm{C}$.

The peroxide number increased in all formulations of lipstick during the storage from 0 until 3 weeks. F0 showed significant increase of peroxide number. The highest peroxide number was observed in $\mathrm{F} 0$ with $1.5 \mathrm{meq} / \mathrm{kg}$ for $27^{\circ} \mathrm{C}$ and $1.7 \mathrm{meq} / \mathrm{kg}$ for $37^{\circ} \mathrm{C}$ after observed for 3 weeks. The different result was observed for $\mathrm{F} 1-\mathrm{F} 5$ at $27^{\circ} \mathrm{C}$ which its peroxide number increased slightly.

In the assay of all formulations of lipstick which were kept at $27^{\circ} \mathrm{C}$ or $37^{\circ} \mathrm{C}$ for 3 weeks, the peroxide number reduce along with the increase of extract concentration added into the formulation of lipstick. FIF5 contained the extract of dragon fruit in different concentration, F5 contain the highest concentration of extract. This result showed that the higher concentration of dragon fruit extract added in the formulation of lipstick, the lower peroxide number of the product which was related with the antioxidant activity of the extract.

The temperature of storage also gives an effect to the peroxide number of lipstick. The result showed that the peroxide number of all formulations at $37^{\circ} \mathrm{C}$ is slightly higher than $27^{\circ} \mathrm{C}$. It presents that the increase of peroxide number is a result of the increase of temperature.

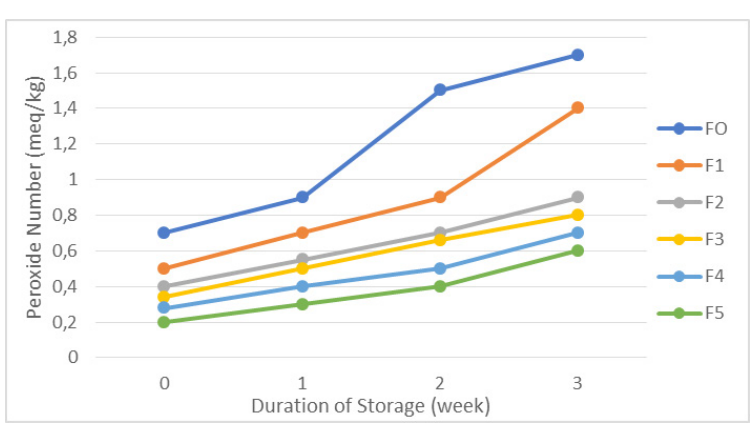

Figure 6. The peroxide number assay of dragon fruit lipstick for storage at $37^{\circ} \mathrm{C}$.

\section{Antibacterial Assay}

Dragon fruit has been known as a source of antibacterial. Based on Melliawati (2009), antibacterial in super red dragon fruit was able to overcome the infection of Staphylococcus aureus. S. aureus is a gram-positive bacterium which grows optimally at $37^{\circ} \mathrm{C}$ and a normal flora which could be found in skin, respiration system, gastrointestinal and lips.

Ciprofloxacin is an antibiotic used as positive control. Based on the assay, positive control in $1^{\text {st }}$ or $3^{\text {rd }}$ weeks of storage period for $27^{\circ} \mathrm{C}$ or $37^{\circ} \mathrm{C}$ shows the high response in the inhibition of the growth of S.aureus. The extract of dragon fruit also represents the inhibition of S.aureus growth in both $1^{\text {st }}$ and $3^{\text {rd }}$ week of storage period. Then, for the formulation of lipstick, F4 shows the positive result for the inhibition of S.aureus, whereas another formulation gives same result as negative control even though it contains extract of dragon fruit. In this study, we observed that the inhibition activity of F4 is higher than the extract itself.

\section{Discussion \\ Secondary Metabolites in Super Red Dragon Fruit}

Extract of super red dragon fruit flesh contains many secondary metabolites that have a lot of benefits. Secondary metabolite is an organic compounds that does not have direct function for the growth and development of plant but is needed for the protection against biotic or abiotic stresses and survivals (Pagare et al., 2015). Through phytochemical screening, several secondary metabolites such as flavonoid, 
tannin and alkaloid have been detected in this extract.

Flavonoids are the largest group of naturally phenolics compounds isolated from a wide range of vascular plant which act in plant as visual attractors, photoreceptors, stress protectants and for light screening (Pietta, 2000). It also has some benefits for human health such as antioxidants, antimicrobials, antivirals, antiallergenic and anti-inflammatory (Pietta, 2000). Super dragon red fruit has red colour in its flesh and rind. According Harivaindaran (2008), the colour pigment of super red dragon fruit consists of anthocyanin, betalain, betacyanin and betaxanthin. Anthocyanin is a flavonoid group with colour pigment from red to blue. It has some biological activities such as primary antioxidants, chelator and scavenger for superoxide anion.

Moreover, tannin is also detected in the dragon fruit extract. Tannin is a phenolics compounds which have complex structure, difficult to be separated and easy to form crystal. Some studies observed the biological activity of tannin as antioxidant, antimicrobial, antitumor and anti-HIV (Yoshizawa et al., 1987, Ho et al., 1999, Ho et al., 2001, Lü et al., 2004, and Gu et al., 2008).

Other secondary metabolites in dragon fruit is alkaloids. Alkaloids is a compound that contain nitrogen atom in its structure. Alkaloids functionates as antimicrobials, antimalarial, cytotoxic and anti-HIV agents (Ang et al., 2000, Iwasa et al., 2001, and Samoylenko et al., 2009).

Through GC-MS analysis, some secondary metabolites in dragon fruit flesh extract have been detected. Some compounds have antioxidant, antibacterial and antimicrobial as shown in Table 3.

\section{Antioxidant Activity of Super Red Dragon Fruit}

Antioxidant level of a compound is represented by $\mathrm{IC}_{50}$ value. $\mathrm{IC}_{50}$ represents the concentration of compounds that can prevent and reduce the oxidation reaction in amount of $50 \%$. In this study, DPPH (1,1-diphenyl-2pycrilhydrazyl) method was used to measure antioxidant activity. DPPH shows absorption at wavelength $517 \mathrm{~nm}$.
Some studies has observed the antioxidant activity of dragon fruit. Fidrianny et al. (2017), studied the antioxidant activity of super red dragon fruit which obtained $\mathrm{IC}_{50}$ value of ethyl acetate flesh extract of super red dragon fruit in $2.69 \mu \mathrm{g} / \mathrm{mL}$. The lowest $\mathrm{IC}_{50}$ indicates the highest antioxidant activity. It could be categorized as a very strong antioxidant.

In this study, the extract of super red dragon fruit flesh has $\mathrm{IC}_{50}$ value $81.55 \mu \mathrm{g} /$ $\mathrm{mL}$. This value is higher than vitamin $\mathrm{C}$ with $\mathrm{IC}_{50}$ value $52.23 \mu \mathrm{g} / \mathrm{mL}$. Based on this result, the antioxidant activity of extract of super red dragon is still lower than vitamin C. However, it can still be classified as strong antioxidant activity.

Super red dragon fruit has antioxidant activity because this fruit contains flavonoids compound which can bind to reactive molecule or free radical species to prevent oxidative reaction.

\section{Evaluation of Super Red Dragon Fruit Lipstick}

Colour pigment from plant or natural sources has been used in many kinds of cosmetics, included the lipstick. According to Aher et al. (2012), herbal lipstick from Bixa orellana seeds had minimal or no side effect which mostly arise in synthetic lipstick. In this study, we developed a lipstick formulation using the colour pigment from super red dragon fruit with different concentration. Then, the stability of lipstick was evaluated in 2 different temperatures, $27^{\circ} \mathrm{C}$ and $37^{\circ} \mathrm{C}$.

Our result showed that the storage at $27^{\circ} \mathrm{C}$ for this lipstick is better than $37^{\circ} \mathrm{C}$. The high temperature causes the evaporation faster than low temperature in lipstick formulation which promote the changes in texture, physical appearance and colour. In the case of formulation, lipstick with high concentration of dragon fruit extract, F3 $(30 \%)$ and F4 (40\%), are more stable than others when was kept at $27^{\circ} \mathrm{C}$. No changes of physical appearance, texture and smell for F3 and F4 during evaluation 3 weeks, except the colour. F3 was the most stable because the changes of colour occurred lately at $3^{\text {rd }}$ week. In accordance with Purbaningtias 
et al. (2017), anthocyanins pigments (red, purple and blue) are sensitive to the changes of temperature, light exposure and $\mathrm{pH}$. The degradation of anthocyanins was influenced by the condition and storage period of the sample.

\section{Peroxide Number and Antibacterial Activity of Herbal Lipstick}

Lipstick contains oil and fatty acid which can undergo hydrolysis or oxidation causing rancid smell. The oxidation process is affected by oxygen availability, light exposure, high temperature, the kind of fatty acid, and storage condition (Ketaren, 1986). In this study, peroxide number assay was performed to measure the number of fatty acid which can undergo oxidation reaction. This assay used iodometric titration for 3 weeks storage.

The result of this assay showed high peroxide number in the lipstick formulation without the dragon fruit extract (base formulation) which was kept either at $27^{\circ} \mathrm{C}$ or $37^{\circ} \mathrm{C}$. It was contrast to the base formulation, lipstick formulation containing dragon fruit extract had low peroxide number. It represented that this flesh extract possesses antioxidant compounds encountering the oxidative reaction. It was correlated with the concentration of extract in the lipstick. The higher concentration of extracts which is added to the formulation, the lower peroxide number that was detected. In GCMS analysis, several compounds having antioxidant activity have been detected (Table 3). According to Winarsi (2007), antioxidant compounds are able to stop oxidant reaction and the formation of free radical molecules.

Apart from being antioxidant, super red dragon fruit has also antibacterial activity. According to Khalili et al. (2012), red pitaya or dragon fruit flesh and peel has have potential against pathogenic food microorganisms, gram positive or negative bacteria. For $S$. aureus, the extract of red pitaya showed high activity of inhibition with the inhibition zones $19.00 \pm 0.43 \mathrm{~mm}$.

The extract of super red dragon fruit flesh resulted the inhibition zones $14 \mathrm{~mm}$ against $S$. aureus, whilst the ciprofloxacin around $28 \mathrm{~mm}$ and $\mathrm{F} 4$ formulation which was stored for 3 weeks at $27^{\circ} \mathrm{C}$ around 20 $\mathrm{mm}$. It showed that $\mathrm{F} 4$ formulation stored at $27^{\circ} \mathrm{C}$ has an antibacterial activity against S. aureus. F1, F2 and F3 did not show any inhibition caused by lower concentration of extract. In the contrast with dragon fruit lipstick F4, the commercial lipstick did not show any antibacterial activity. Inhibition zone which is higher or around $20 \mathrm{~mm}$ indicates the inhibition response of $S$. aureus growth (Brooks, 2007). This result corresponded to (Khalili et al., 2012), that red dragon fruit flesh has antibacterial activity, in particular S. aureus. Then, based on the study, storage temperature affected the activity of compounds in the inhibition of $S$. aureus growth. No antibacterial activity of F4 lipstick formulation after stored at $37^{\circ} \mathrm{C}$ for 3 weeks, whilst at lower temperature, $27^{\circ} \mathrm{C}$, the antibacterial activity was still high in F4 formulation. Although F1, F2, and F3 have also contained the extract of dragon fruit, no antibacterial activity has been observed for these formulations at both storage temperature. It represents that the concentration of extract less than $40 \%$ in the sample of lipstick could not inhibit the growth of $S$. aureus effectively. The effect of storage temperature needs to be studied in detail.

\section{Conclusion}

The extract of super red dragon fruit flesh can be used as colorant in herbal lipstick with storage period for 3 weeks at $27^{\circ} \mathrm{C}$ and 2 weeks at $37^{\circ} \mathrm{C}$. The antioxidant activity of this extract was $81.55 \mu \mathrm{g} / \mathrm{mL}$. This activity was also indicated by low peroxide number of super red dragon fruit lipstick at different concentration of extract. The best formulation for this herbal lipstick was F4 formulation. This formulation showed the high stability when was stored at $27^{\circ} \mathrm{C}$ for 3 weeks. Moreover, F4 formulation had an antibacterial activity against $S$. aureus when was kept at $27^{\circ} \mathrm{C}$.

\section{References}

Aher, A., Kadaskar, P. T., Bairagi, S., \& Desai, S. S. (2012) Formulation and evaluation of herbal lipstick from colour pigments 
of Bixa Orellana (Bixaceae) seeds, International Journal of Pharmacy and Pharmaceutical Sciences, 4(5), 357-359.

Ang, K. K., Holmes, M. J., Higa, T., Hamann, M. T., \& Kara, U. A. (2000) In vivo antimalarial activity of the betacarboline alkaloid manzamine A, Antimicrobial Agents and Chemotherapy, 44(6), 1645-1649.

Aydin, R. (2005) Conjugated linoleic acid: chemical structure, sources and biological properties. Turkish Journal of Veterinary Animal Science, 29(2), 189-195.

Azam, M. M., Waris, A., \& Nahar, N. M. (2005) Prospects and potential of fatty acid methyl esters of some nontraditional seed oils for use as biodiesel in India, Biomass and Bioenergy, 29(4), 293-302.

Balasundram, N., Sundram, K., \& Samman, S. (2006) Phenolic compounds in plants and agri-industrial by-products: Antioxidant activity, occurrence, and potential uses, Food Chemistry, 99(1), 191-203.

Devi, J \& Muthu, A. K. (2014) Gas Chromatography-Mass Spectrometry Analysis of Bioactive Constituents in The Ethanolic Extract of Saccharum spontaneum Linn, International Journal of Pharmacy \& Pharmaceutical Sciences, 6(2), 755-759.

Elezabeth, D.V \& Arumugam, S. (2014) GC - MS Analysis of Ethanol Extract of Cyperus rotundus Leaves, International Journal of Current Biotechnology, 2(1), 19-23.

Fidrianny, I., Ilham, N., \& Hartati, R. (2017) Antioxidant profile and phytochemical content of different parts of super red dragon fruit (Hylocereus costaricensis) collected from West Java-Indonesia, Asian Journal of Pharmaceutical and Clinical Research, 10(12), 290-294.

Figueiredo, A. C., J. G. Barroso., L. G. Pedro., \& J. J. C. Sheffer. (2008) Factors affecting secondary metabolite production in plants: volatile components and essential oils, Flavour Fragr. J., 23, 213-226.

Ghosh, S., Banerjee, S., \& Sil, P. C. (2015) The beneficial role of curcumin on inflammation, diabetes and neurodegenerative disease: $A$ recent update, Food and Chemical Toxicology.

Gu, H. F., Li, C. M., Xu, Y. J., Hu, W.F., Cen, M.H., \& Wan, Q.H. (2008) Structural features and antioxidant activity of tannin from persimmon pulp, Food Research International, 41(2), 208-217.

Harivaindaran K.V., Rebecca O. P. S., \& Chandran, S. (2008). Study of optimal temperature, $p H$ and stability of dragon fruit (Hylocereus costaricensis) peel for use as potential natural colorant. Pak. J. Biol. Sci. 11(18): 2259-2263.

Ho, K. Y., Huang, J. S., Tsai, C. C., Lin, C. C., Hsu, Y. F., \& Lin, C. C. (1999) 'Antioxidant Activity of Tannin Components from Vaccinium vitisidaea L.', Journal of Pharmacy and Pharmacology, 51(9), 1075-1078.

Ho, K. Y. Tsai, C. C., Huang, J. S., Chen, C. P., Lin, T. C., \& Lin, C. C. (2001) Antimicrobial activity of tannin components from Vaccinium vitis-idaea L., Journal of Pharmacy and Pharmacology, 53(2), 187-191.

Iwasa, K., Moriyasu, M., Tachibana, Y., Kim, H.-sook, Wataya, Y., Wiegrebe, W., \& Lee, K. H. (2001) Simple isoquinoline and benzylisoquinoline alkaloids as potential antimicrobial, antimalarial, cytotoxic, and anti-HIV agents, Bioorganic and Medicinal Chemistry, 9(11), 2871-2884.

Khalili, R. M. A., Abdullah, A. C., \& Manaf, A. A. (2012) Antibacterial Activity of Flesh and Peel Methanol Fractions of Red Pitaya, white Pitaya and Papaya on Selected Food Microorganisms, International Journal of Pharmacy and Pharmaceutical Sciences, 4, 185-190.

Lü, L., Jiang. S. B., Liu, S., \& Wu, S. G. (2004) Tannin inhibits HIV-1 entry by targeting gp41, Acta Pharmacologica Sinica, 25(2), 213-218.

Melliawati, R. (2009) Escherichia coli dalam Kehidupan Manusia', Biotrends. Elsevier, 4(1),10-14.

Pagare, S., Bhatia, M., Tripathi, N., \& Bansal, Y. K. (2015) Secondary metabolites of plants and their role: Overview, Current 
Anjarsari et al.

Trends in Biotechnology and Pharmacy, 9(3), 293-304.

Pietta, P. G. (2000) Flavonoids as antioxidants, Journal of Natural Products, 63(7), 10351042.

Purbaningtias, T. E., Aprilia, A. C., \& Fauzi'ah, L. (2017) The Study of Temperature and UV Light Effect in Anthocyanin Extract from Dragon Fruit (Hylocereus costaricensis) Rind using UV-Visible Spectrophotometer, AIP Conference Proceedings, 1911, 1-5.

Samoylenko, V., Jacob, M. R., Khan, S. I., Zhao, J., Tekwani, B. L., Midiwo, J. O., Walker, L. A., \& Muhammad, I. (2009) Antimicrobial, Antiparasitic and Cytotoxic Spermine Alkaloids from Albizia schimperiana, Natural Product Communications, 4(6), 791-796.

Sangi, M., Runtuwene, M. R. J., \& Simbala, H. E. I. (2008) Analisis Fitokimia Tumbuhan Obat Di Kabupaten Minahasa Utara, Analisis Fitokimia Tumbuhan Obat Di Kabupaten Minahasa Utara, 1(1), 47-53.

Timothy, S. Y., Wazis, C. H., Adati, R. G., \& Maspalma, I. D. (2012) Antifungal activity of aqueous and ethanolic leaf extracts of Cassia alata Linn, Journal of Applied Pharmaceutical Science, 2(7), 182-185.

Uma, B., Prabhakar, K., Rajendran, S., \& Sarayu, L. (2009) Studies on GCMS spectroscopic analysis of some bioactive antimicrobial compounds from Cinnamomum zeylanicum, Journal of Medical Plants, 8(31), 125-131.

Wijaya, M., Noor, E., \& Irawadi T. T. (2008) Karakterisasi komponen kimia asap cair dan pemanfaatannya sebagai biopestisida, Bionature, 9(1), 34-40.

Winarsi, Hery. (2007). Antioksidan Alami dan Radikal Bebas Potensinya dan dalam Kesehatan. Yogyakarta: Kanisius.

Yatagai (2002) Utilization of charcoal and wood vinegar in Japan. Graduate School of Agricultural and Life Science. Tokyo : The University of Tokyo.

Yoshizawa, S., Horiuchi, T., Fujiki, H., Yoshida, T., Okuda, T., \& Sugimura, T. (1987) Antitumor promoting activity of
Sciscitatio, Vol. 1, No. 1, Januari 2020

(-) epigallocatechin gallate, the main constituent of "Tannin" in green tea, Phytotherapy Research, 1(1), 44-47.

Zhao, J., Mou, Y., Shan, T., Li, Y., Zhou, L., Wang, M., \& Wang, J. (2010) Antimicrobial Metabolites from the Endophytic Fungus Pichia guilliermondii Isolated from Paris polyphylla var. yunnanensis, Molecules, 15(11), 7961-7970. 